\title{
Professional Experience in Australian Initial Teacher Education: An Appraisal of Policy and Practice
}

\author{
Susan Ledger ${ }^{1}$, Christine Ure ${ }^{2}$, Madeline Burgess ${ }^{1} \&$ Chad Morrison ${ }^{3}$ \\ ${ }^{1}$ Murdoch University, Australia \\ ${ }^{2}$ Interim Executive Dean of the Faculty of Arts and Education and Inaugural National Chair of the Network of \\ Associate Deans of Professional Experience, Australia \\ ${ }^{3}$ Curtin University, Australia \\ Correspondence: Madeline Burgess, Murdoch University, Australia. E-mail: m.burgess@ murdoch.edu.au
}

Received: October 13, 2020

Accepted: November 10, $2020 \quad$ Online Published: November 18, 2020

doi:10.5539/hes.v10n4p116

URL: https://doi.org/10.5539/hes.v10n4p116

\begin{abstract}
Legislative guidelines regulate professional experience within initial teacher education (ITE) but little is known about teacher educators' perspectives on how these guidelines are operationalised. ITE providers, in collaboration with school partners, implement a range of programs designed to develop pre-service teachers' 'classroom readiness'. We examine how current legislation influences the delivery of professional experience, the provision of funding, and support for university-school partnerships and in-school supervision. This analysis highlights ambiguities in the interpretation of the legislative guidelines, creating a disconnection between policy and practice, an over-reliance on the 'good will' of key stakeholders, and competing demands between the 'actual' and 'hidden' costs of professional experience. Without reform of both policy and practice ITE providers will continue to be constrained when attempting to meet regulatory expectations. These findings demonstrate a need for government departments and ITE regulators to work more closely to improve integration of policy and practice for professional experience.
\end{abstract}

Keywords: school-university partnerships, initial teacher education, professional experience, educational reform, educational policy

\section{Introduction}

Globally, universities are being scrutinised for the effectiveness of their programs in preparing graduates for future employment in the $21^{\text {st }}$ century (Teacher Education Ministerial Advisory Group [TEMAG], 2014). Given the prominent role that education has in shaping and re-shaping the needs of our society, Initial Teacher Education (ITE) programs have received noticeable attention, particularly in relation to the 'classroom readiness' of graduate teachers to meet the demands of teaching in the $21^{\text {st }}$ Century (Gore, 2015; TEMAG, 2014). Demonstrating practical skills in the classroom requires an understanding of multiple aspects of teaching and learning, as articulated in the Graduate Standards (AITSL, 2017b). However, it is feasible that a graduate might meet the Standards, but may not be 'classroom ready', and may not have the 'practical skills needed for the classroom' (TEMAG 2014; Le Cornu, 2015). This problem appears to arise when the school and university elements of ITE programs are not well integrated. High quality professional experience programs that provide pre-service teachers with a coherent university- and in-school- program of learning to teach are imperative in the preparation of classroom ready teachers at graduation (McLean, Dickson, Rickart, Dinham, Conroy, \& Davis, 2015).

In Australia, at any one time over 81,000 pre-service teachers are enrolled in one of the 375 ITE programs offered by 48 accredited providers in 89 metropolitan and regional locations (AITSL, 2019a). Professional experience in schools is regarded as the single most important element of ITE (see for example, Le Cornu, 2010; Ramsey, 2000; House of Representatives Standing Committee on Education and Vocational Training [HRSCEVT], 2007), where pre-service teachers have a "structured opportunity" to develop and demonstrate their skills in the classroom, and "demonstrate a positive impact on student learning" (AITSL, 2015). Professional experience is highly valued among pre-service teachers and is often considered to be the "most influential factor" of their teacher education (Southgate et al., 2013; Wilson, 2006). 
Yet despite the importance attributed to professional experience, the practicum is consistently an area of policy concern, and Australian universities are increasingly being asked to account for the effectiveness of their programs, due to the perceived lack of 'classroom readiness' among graduate teachers (Aprile \& Knight, 2019; Loughran, 2014; Department of Education and Training, 2015).

Since the 1970s, Australia has seen more than 100 reviews and public inquiries into ITE, which have extensively researched, analyzed and problematised professional experience (Bahr \& Mellor, 2016; HRSCEVT, 2007; Mayer, 2014; Ramsey, 2000; Smith \& Lev-Ari, 2005; Teaching Australia, 2006; ). In particular, they have highlighted concerns over both the operation and funding of professional experience, as outlined in the following reports tabled in the last two decades:

The traditional model of practical experience, under direct supervision of professionals, is becoming increasingly difficult to provide due to limited availability of placements and financial constraints in universities (Ramsey, 2000).

Further,

The problems with practicum have been outlined in nearly every report addressing teacher education in the last decade. The fact that these problems have still drawn so much attention in this inquiry indicates the need for major reform in this area, involving all major players and all members of the system. (HRSCEVT, 2007 p. 73)

Currently, the Australian Institute for Teaching and School Leadership (AITSL) is the federal statutory authority that, amongst other responsibilities, provides national leadership in relation to teacher standards, accreditation of ITE (including pre-service teacher professional experience) and ongoing teacher professional growth (AITSL, 2017a; 2018). The Australian Professional Standards for Teachers (APST) are the standards mandated by AITSL that stipulate the competencies that graduating teacher must have achieved in their teaching and professional experience practice. These standards are said to "constitute agreed characteristics of the complex process of teaching" (AITSL, 2019a). The 2011 National Framework underpins teacher registration in Australia for Teacher Registration; the APSTs are embedded within this framework.

Initial teacher education providers in Australia must adhere to national accreditation and registration demands; however, there is considerable variability among the structure, delivery and funding of ITE professional experience across states (Ingvarson, Reid, Buckley, Kleinhenz, Masters, \& Rowley, 2014; AITSL, 2019a). All pre-service teachers are required to meet the minimum number of supervised practicum days in schools with "no fewer than 80 days in undergraduate and double-degree teacher education programs and no fewer than 60 days in graduate-entry programs" (AITSL, 2019a). The programs offered may include a supervised practicum, un-supervised field-based community practicum, school observations and immersion in-school experiences. Other programs offer a 12-month internship under the general supervision of a mentor, or a combination of all these models (AITSL, 2014; Mayer, 2014).

Initial teacher education programs are funded and regulated by the Australian Government, with students paying a contribution towards the cost of their degree program (Higher Education Support Act [HESA], 2003). Beyond this, ITE is a state responsibility and each state has their own distinct model for ITE. This includes differences in whether state governments provide any additional funding to support the delivery of the professional experience component of ITE, or not. There are also differences in how much supervising teachers are paid for mentoring pre-service teachers when they are on placement. There is considerable variation in the award payment for supervisors since the termination of The Australian Higher Education Practice Supervision Award of 1990 by Fair Work Australia in 2011, and at present there is no legislation that outlines whether, or how much teachers should be paid as supervising teachers (Mayer, 2014). The termination of this agreement implies a lack of legislative obligations; however, at present most ITE providers respond to the expectations of school teachers by paying a minimum of $\$ 30$ per day to school teachers and school teacher coordinators for each day of supervised placement.

Initial teacher education providers are required to establish "enduring school partnerships", which includes building relationships with schools and university-based supervisors and mentors (AITSL, 2011a). It is expected that the mentoring teacher provides support for pre-service teachers by helping them make connections between the classroom experiences and to apply the theoretical and evidence based processes they have learnt through their on campus studies (Renshaw, 2012). However, as noted by Le Cornu (2015) selection of supervising teachers is based on length of teaching service, rather than expertise or qualifications for supervision. This issue has been documented previously, where allocations for workload or professional progression linked to coordination and supervision for ITE are not made explicit by employers (see HRSCEVT, 2007, p. 70). At a 
state level, professional roles and responsibilities for the conduct of professional experience and supervision are omitted (e.g. NSW Department of Education, 2017) or mentioned as a leadership activity, but are not clearly defined (Victoria State Government, 2016). The only place where this role counts for any form of professional recognition is within a teacher's documented portfolio of evidence that is submitted to teacher registration authorities for advancement in teacher registration status from Proficient to Highly Accomplished levels. While this advancement designates teacher capability and status, it has no impact on employment status or pay scales (AITSL, 2015).

However, whilst there are expectations concerning payment of supervisors and university-school partnerships, professional experience is not mentioned in the School Education Act (2013), the HESA (2003), or in the School Education Regulations (2000). In the Standard of Practice (Department of Education and Training, 2016), professional experience is only mentioned once in the 'proficient' level requirements of the AITSL Professional Standards for Teachers.

In this study, we examine how ITE providers across Australian universities perceive the operationalisation of current legislative guidelines that inform pre-service professional experience. We explore the complex space in which ITE providers must operate by examining the tensions between legislative policy and operationalisation of ITE professional experience. This study is of relevance to the international audience because it provides a contextual, theoretical and legislative case study of the tensions that may exist between policy and practice in ITE professional experience that are not typically explored in research. This study was guided by three research questions:

1. How do ITE providers perceive the operationalisation of current legislation that informs professional experience, with respect to funding, university-school partnerships and supervision of pre-service teachers?

2. To what extent do existing arrangements provide the conditions needed for effective ITE professional experience placements?

3. What tensions exist between policy and practice in ITE professional experience, policy, practices and programs?

\section{Literature Review}

\subsection{ITE Professional Experience in Australia}

The context of reviewing ITE professional experience lies within a broader policy discussion on accountability in higher education across Australia (Mayer, 2014). Government policies at a national level are aimed at increasing accountability, productivity and quality across all levels of education, including teacher education (Department of Education, Employment and Workplace Relations (DEEWR), 2009). In 2007, the Australian Labor Party launched their 'education revolution', making education a priority at a federal level, stating that "a substantial and sustained increase in the quality of our investment, and the quality of our education . . . is required at every level of education" (HRSCEVT, 2007).

The Bradley Review of Higher Education launched in 2008 (published under the title, Transforming Australia's Higher Education System) focused specifically on the future direction of higher education, and was seen as an important step in shaping the goals of higher education towards greater productivity within broader economic goals (DEEWR, 2009). In 2008, the National Partnerships reform agenda also emerged (National Partnership Agreement on Improving Teacher Quality), signalling new ways for schools and university providers of ITE to work together (Council of Australian Governments, 2009). The National Partnership Agreement aimed to deliver "system-wide reforms" through targeting critical points in initial teacher education, such as professional experience, as a way of improving the preparation and development of pre-service teacher (White, Bloomfield, \& Le Cornu, 2010).

Contemporary discourse on education continues to be fuelled by a political agenda that focuses on economic and productivity goals, while emphasising teaching and learning outcomes that need to be produced and measured (Clinton et al., 2017). It has been argued that the current neo-liberal political climate has increased expectations of accountability and conformity to professional standards frameworks across all aspects of ITE (Bloomfield, 2009).

Current legislation on professional experience is thus situated within a macro political reform agenda of nationally agreed goals for improving effectiveness and accountability in teacher education (Le Cornu \& Ewing, 2008; TEMAG, 2014). 


\subsection{Funding of ITE Professional Experience}

The Australian Government is the primary provider of funding for ITE. The provision of funding for ITE is detailed in the legislation outlined in the HESA (2003). A report prepared for the Department of Education and Training (2017) noted that delivery mode of the program has an important implications for course costs and that "disciplines that include supervised work placements, a relatively high number of contact hours, smaller class sizes or more resource-intensive delivery (e.g. laboratories, seminars or workshops) are likely to be more expensive to teach" while "disciplines or universities that teach a high proportion of students externally through online or distance education may have lower teaching and scholarship costs" (p. 51).

Although it has been established that supervised work placements cost more in Education than in other disciplines (DEEWR 2011), figures in 2017 showed that placement loading for ITE does not cover the actual cost of the broad range of activities required, including the administration of placements and supervision payments to teachers; the preparation of mentor teachers; visits to pre-service teachers while on placement; in-school work with mentors to foster collaborative approaches; supervision and assessments of pre-service teachers; payments to supervising teachers and placement coordinators in schools; and, the cost of academic staff time in advising and supporting pre-service teachers and school staff. Additional costs may include establishing school partnerships.

The ongoing pressure from the Australian Education Union (AEU) to continually review and increase payments for supervisory teachers has resulted in state-wide changes. For example, in South Australia, payments are managed through the Department of Education and are linked to salary increases in response to CPI adjustments. In New South Wales, teacher education providers entered into a joint agreement with the AEU for a three year agreement for supervision payments with annual increments in 2016 and 2017. The issue of rising costs for courses with placements due to rising salary costs of external agencies was noted in the Deloitte review on Higher Education teaching and learning costs in higher education (Department of Education and Training, 2017).

Due to the embedded practical component of ITE, education courses are unsuited to low-cost teaching methods. Research shows that high quality learning in education incorporates pedagogical approaches that are resource intensive, including models of seminars and workshops, and more recently, next generation simulation platforms. Education courses offered in distant mode require intensive interactions in one to one or small group mode to ensure the integration of teaching theory to teaching practice. Further, in regard to placement supervision, the current practice of making a daily supervision payment to a supervisory teacher does not reflect the approach or resources needed to support high quality professional practice placements in schools. Research into the placement needs of pre-service teachers has shifted the focus of learning in placements from the preparation and delivery of lessons under the guidance of a single teacher to applied professional learning models that are supported within a community of practice (Lave \& Wegner, 1999). A common feature of these models is the engagement of pre-service teachers in collaborative work with several teachers in the school community and the academic community of their provider institution. Collaborative approaches such as these are designed to ensure that, as pre-service teachers learn to teach, they acquire the broader range of professional knowledge and practices reflected in the National Professional Standards for Teaching (AITSL, 2011b).

\subsection{University-school Partnerships}

In efforts to foster more effective university-school partnerships, one approach has been to focus on forming better integration between theoretical content and practical experiences (Ingvarson et al., 2014 p. 22). Many university-school partnerships exist with individuals working in isolation and without active engagement from partnership teams (Kruger, Davies, Eckersley, Newell, \& Cherednichenko, 2009). Partnership programs resulting from National Partnership funding 2009-2015 have addressed some of these concerns; however, many of these outcomes have only achieved ad hoc changes rather than systemic improvements.

Concern has been raised over the quality of university-school partnerships that are not facilitating the conditions necessary for pre-service teachers to acquire the practical skills they need to become effective teachers (see for example, TEMAG, 2014). Reciprocal partnerships between providers and schools are perceived to be inadequate for the management of the complexities of professional experience, or to integrate professional experience with course work and theory (TEMAG, 2014). Indeed, the lack of effective partnerships between university providers and schools has been cited as one of the key problem areas in teacher education (Le Cornu, 2015). A lack of funding to build and strengthen these partnerships contributes to their longevity (Green, Tindall-Ford \& Eady, 2020). Without adequate funding, essential elements of partnership activities remain limited, as they are too costly to operationalise. 


\subsection{Mentoring Models}

Grossman (2010) argued that the relationship between the intern and mentor at a classroom level is a vital component of the professional experience process and has the greatest impact on student learning. Similarly, Cohen et al. (2013) writes, "The individual relationships between mentors, supervisors, and pre-service teachers were attended by tension and conflicts ensuing from different interests, educational philosophies, and status differences" (p. 345). However, identifying suitable mentors and maintaining quality supervision has been identified as one of the "perennial issues in professional experience" (Cohen et al., 2013; HRSCEVT, 2007; TEMAG, 2014). These studies showed that there are inbuilt points of contestation and vulnerability for different stakeholder groups within the relationship between university, sectors, schools and personnel that all influence the success of the mentoring relationship. Compounding the problem is that no legislation currently outlines exactly what is expected of mentors in the context of ITE professional experience and there is no reward or recognition for high quality mentors within the system.

In describing the roles and responsibilities of supervising teachers, AITSL (2015) requires that supervisory teachers must "act as a role model to pre-service teachers by participating actively in all aspects of a teacher's professional life" and must "demonstrate a commitment to partnerships" (p. 4). AITSL (2015) states further that the role of the supervising teacher also includes "collaboration with the professional experience coordinator" and "demonstrate a clear commitment to supervising and developing pre-service teachers with a focus on helping them understand and improve their impact on student learning" (p. 4). The tasks of effective supervisory teachers also include 'fostering a culture' that encourages pre-service teachers to 'engage', 'reflect' and 'collaborate' (AITSL, 2015).

Other policy documents state that supervising teachers are expected to have a broad range of "training and skills" that are necessary to effectively supervise and assess pre-service teachers' professional experience placements (TEMAG, 2014). Further, supervisory teachers should have "expertise and be supported in coaching and mentoring, and in making judgments about whether students have achieved the Graduate Teacher Standards" (AITSL, 2011a). Supervising teachers are therefore required to be "highly skilled . . . who are accomplished adult educators as well as expert teachers, equipped to play the pivotal role they are assigned in these programs" (AITSL, 2014).

Given the range of tasks that is expected of supervisory teachers by AITSL, it is noteworthy that the role of the supervisory teacher is not made explicit in government policies. Legislation governing teacher training, practice and job description does not explicitly address the tasks required of supervisory teachers. In particular, professional experience is not mentioned in the School Education Act (1999) or the School Education Regulations (2000). In NSW, for example, there is no mention of the role of the supervisory teacher in the description of professional responsibilities for teachers (NSW Department of Education, 2017). Similarly, there is no description of professional responsibilities for the supervisory teacher in other Australian states (Victoria State Government, 2016).

As previously outlined, there is also considerable ambiguity surrounding the payment of supervisory teachers. The Australian Government funding to higher education institutions for ITE includes an amount for the conduct of professional experience, although this is not specifically tagged for the payment of supervising teachers. It is money for providers to use for placement related activities and not designed as the payment for teachers. Since the 1990s, an Industrial Award, the Australian Higher Education Practice Teaching Supervision Award 1990, provided guidelines for the eligibility of teachers for practicum supervision as well as the rates for payment for supervising in all Australian States and Territories. While the award was terminated by Fair Work Australia in 2011, as part of an award-modernisation process, most universities continue to offer the same rate of funding to teachers and/or schools, or have increased the payment (Mayer, 2014).

Payment for supervisory teachers exists according to payment structures of the 1990s, and there is little evidence that other incentives, such as time off in lieu or opportunities for professional development, are used to encourage teachers to supervise pre-service teachers. This is particularly problematic in rural and remote areas where access to teacher relief is limited. Teachers who supervise pre-service students generally do not receive any form of accreditation or formal recognition for taking on the responsibility (HRSCEVT, 2007 p. 70). The lack of formal or informal recognition in policy documents or government legislation for supervisory teachers raises the question as to whether supervisory teachers are expected to fulfil a complex range of tasks purely out of their own professional responsibility or 'good will'.

These issues form the background to the present study that focuses on the perceptions of ITE providers and those directly involved in the provision of professional experience. 


\section{Methodology}

This study was exploratory in design and used a qualitative approach (Denzin \& Lincoln, 2008) to investigate how providers of ITE across Australian universities perceive the operationalisation of current legislative guidelines. We explored the views of ITE providers on pre-service professional experience, to reveal the convergence and divergence between policy texts and the operational practices of professional experience. We investigated participants' views on three interrelated areas of professional experience: (i) funding, (ii) creating and maintaining university-school partnerships, and (iii) the roles and responsibilities of supervising/mentor teachers.

\subsection{Participants and Study Procedure}

This study was based on a qualitative research design (Creswell \& Poth, 2018; Denzin \& Lincoln, 2008). For the purposes of data collection, an online questionnaire was developed by the authors to elicit the perceptions of ITE providers on aspects of pre-service professional experience.

A pilot study in the form of an online survey was developed and administered via email to representatives from the Network of Academic Directors of professional experience (NADPE), a subset of the Australian Council of Deans of Education (ACDE). The purpose of the pilot study was to reveal gaps and inconsistencies in the survey design, and based on respondent feedback, amendments were made to the questions in the online survey.

In the second phase (May 2017), all academics and regulators of ITE professional experience across Australian universities, including state representatives of Faculties/Schools of Education, were invited to participate in the online survey $(n=48)$. Twenty completed surveys were returned $(n=20)$ representing $42 \%$ of all Australian Higher Education ITE providers. Participants were informed of their rights according to the guidelines stipulated by the National Statement on Ethical Conduct in Human Research (National Health and Medical Research Council, 2007), and the Australian Code for the Responsible Conduct of Research (National Health and Medical Research Council, 2018) and the project was approved by the Murdoch University Human Research and Ethics Committee (2017/109). Participants were asked to answer questions on the following:

- University demographic and background

- Funding models and management of finances

- Mentoring models and any challenges in the current model of professional experience

- The roles and responsibilities of supervising/mentor teachers

Questions required participants to either tick boxes, provide short dot-pointed answers, or provide short answers.

\subsection{Data Analysis}

The data analysis followed the guidelines for qualitative analysis described by Miles and Huberman (1994) which involved three steps:

1. The first step involved data reduction, "the process of selecting, focusing, simplifying the data" (Miles $\&$ Huberman, 1994 p. 10), which involved writing summaries and identifying themes from the dot-point questions on surveys were initially collated into tables in Excel under section headings and categories.

2. In the next step, qualitative "data display" coding (Miles \& Huberman, 1994) involved summarising and categorising participants' responses to open-ended statements according to similarities of the themes.

3. Third, we identified patterns and grouped participants' responses into themes and subthemes. These themes and subthemes were recorded in separate tables in Excel.

The steps outlined above involved making handwritten notes on hard copies of survey responses, and then organising the data into Excel spreadsheets so that the frequency with which subthemes were described and the number of participants who described particular themes could be easily identified. The reliability of the data analysis process was enhanced through collaboration and discussion among the authors throughout each step of the analysis.

\section{Findings}

Analysis of data revealed participant views and perceptions of how professional experience is operationalised in Australian ITE. The following sections present the findings from the online survey relating to financial costs of practicum placements, university-school partnerships, and the roles of the supervisory teacher. We begin with the demographic information from participating ITE providers. All provider-participants were assigned pseudonyms (e.g. P1, P2), and data is presented as their participant number, followed by the location of their institution (e.g. P1, VIC). 
Table 1 shows that the sample of respondents included participants from all 8 Australian states, giving data from all Australian states, although at varying levels of representation. The highest number of responses came from participants in Victoria and NSW, reflecting the larger the number of providers in these states. Responses for Victoria, South Australia and ACT represented 50\% of each state sample and was $40 \%$ for WA, $29 \%$ for New South Wales and $11 \%$ for Queensland. Tasmania and NT have only one provider $(100 \%)$ each, and one provider did not identify their state and was recorded as unknown $(U)$.

Table 1. Participants by location of institution and proportion of respondents surveyed

\begin{tabular}{llll}
\hline $\begin{array}{l}\text { Australian } \\
\text { State/Territory }\end{array}$ & $\begin{array}{l}\text { No. of } \\
\text { respondents (n) }\end{array}$ & $\begin{array}{l}\text { No. of ITE } \\
\text { providers per state }\end{array}$ & $\begin{array}{l}\text { Proportion of } \\
\text { respondents (\%) }\end{array}$ \\
\hline VIC & 6 & 12 & $50 \%$ \\
NSW & 5 & 17 & $29 \%$ \\
WA & 2 & 5 & $40 \%$ \\
SA & 1 & 4 & $50 \%$ \\
NT & 1 & 1 & $100 \%$ \\
QLD & 1 & 9 & $11 \%$ \\
ACT & 1 & 2 & $50 \%$ \\
TAS & 1 & 1 & $100 \%$ \\
Unknown (U) & 1 & - & unknown \\
\hline Total & 20 & 48 & $42 \%$ \\
\hline
\end{tabular}

${ }^{1}$ Australian Institute for Teaching and School Leadership, (2019b)

\subsection{Financial Costs of Practicum Placements}

Some ITE provider-participants reported costs associated with the provision of professional experience placements ranged from approximately $\$ 200000$ to $\$ 2500000$. However, more than half of these respondents (60\%), who were academics with high levels of responsibility for professional experience, reported that they had 'no idea' of the annual costs of running pre-service teacher placements, as noted by P8 from NSW: "I have never seen a 'professional experience budget". And further, participants commented on the lack of clarity surrounding payment of supervising teachers, even though there is no award payment: "Teacher mentors are paid what was the agreed rate negotiated with AEU, even though this agreement is no longer current. Some other providers pay more and this puts pressure on us to match" (P15, VIC).

The ambiguity around the running costs of placement and payment of supervising teachers raises three key issues of concern. The first is that there is an expectation for providers to make a payment to teachers or schools for each placement day for each pre-service teacher to ensure placement availability. All participants $(n=20)$ commented on the variability in pay to supervisors, and while there is no mandated award payment and that while providers are not obligated to make payments at any particular rate, the past practice of a payment of $\$ 21.40$ per day for supervision and $\$ 1.30$ per day for coordination as determined by the 1990 Australian Higher Education Practice Supervision Award has created ongoing expectations from school-based supervisors and coordinators for a payment.

The AEU has been an active supporter for payments to continue to teachers and it has encouraged providers to consider increasing payments to match CPI rises that have occurred since 1990. The issue for providers is that if they do not continue to pay the daily rate for supervision, teachers will not make placements available to universities. Providers have increased payments over time to respond to objections from teachers and the AEU.

A second issue of concern is that the total cost of payments for supervision exceeds the amount of income received by providers for the practicum funding allocation, which forms a component of ITE university student fee income. This affects other elements of the pre-service program delivery. The total sum of a daily payment for each student placement represents a substantial budget component, with larger providers reporting the total costs for placement payments amounting to $\$ 1.5-2.5 \mathrm{~m}$ of their annual budget. The key outcome from these payments is simply an assurance that placements are made available to providers.

One provider-participant commented on this as a lost opportunity, stating, "If I could spend 1.2 - 1.5 million on professional development for schools then we could be meeting school requirements and doing it cost effectively" (P25, NSW). The lack of government regulation over the use of the practicum funding allocation or payment rates for supervisors creates pressures for providers. As explained by P28:

[We] pay $\$ 28.50$ per day for supervising teachers per pre-service teacher per day and $\$ 1.50$ per day for 
school coordinators. These rates increased in 2016 from $\$ 21.40$ per day due to pressure from other institutions paying more. The [University] pays this rate for all students regardless of the placement model. The AEU started a campaign in Victoria in 2015 as all providers were only paying a total of \$24 per day for supervision and coordination and this was less than payments that had been agreed to in NSW (P28, VIC).

A third concern noted by participants was the hidden costs associated with facilitating placements not accounted for in staff salaries. The hidden costs identified are summarised in Table 2 below.

Table 2. 'Hidden costs' in operationalising professional experience

\begin{tabular}{ll}
\hline Theme & Sub-theme \\
\hline Inadequate time allocation & Relational work of professional experience is not recognised; \\
& Not enough time to build relationships; \\
& Time taken to build working relationships not factored into workload \\
& Time taken for travel and student support not factored into workload \\
& Additional assistance needed for certain pre-service teachers not \\
Inadequate funding & accounted for in operational costs \\
Emotional costs & Stress involved in securing placements under time pressure \\
& not recognised in workload \\
& Stress of dealing with failing or at-risk pre-service teachers \\
& not recognised in workload \\
\hline
\end{tabular}

The hidden costs reported by provider-participants refer to the relational work of ITE professional experience not explicitly recognised within financial allocation or workload models for academics who support placement activities. The capacity to work with early learning centres/schools/colleges where placements are conducted relies on a positive relationship with site staff, and this is not recognised within the current organisational structure. As a result, the formalised performance measures remain in addition to the sizeable workload of the professional experience team. As expressed by one provider-participant, "The allocation of staffing never adequately meets these pressures" (P22, TAS). Similarly P15 (VIC) commented, "Effective Professional Experience relies on productive partnerships with schools. It takes considerable time to establish these partnerships and then to sustain them each year. These costs are not recognised in [University]." Other participants noted that, "time is a huge hidden cost" (P9, QLD), and in that, "time (is needed) to build the relationships and maintain them" (P21, NSW).

Academics provide considerable support to pre-service teachers, but this service is not recognised in payment or workload. As explained by one respondent:

Time [University] staff give to supporting preservice teachers generally exceeds those claimable . . . [this reflects] time taken away from teaching, supervision and administration responsibilities to ensure good working relationships with host schools maintained (P19, SA).

As a result, providers tend to rely on the goodwill of schools and supervising teachers in facilitating professional experience, particularly when demands increase due to placement difficulties. This is not taken into consideration in current funding arrangements for professional experience, as explained by P8 below:

There is a massive component of goodwill on the part of schools and individual classroom teachers that is not accounted for in any financial sense with reference to the school-based element of professional experience. Many university-based supervisors also go beyond the 'call of duty' in the routine sense of the term. The distress for school-based and university-based staff associated with poorly performing [preservice] students in general and with failing students in particular also has no financial cost attached to it. There is also a considerable cost associated with student withdrawals and appeals associated with failing students that is not accounted for (P8, NSW).

Participants commented further that "finding placements is expensive" (P25, NSW), and "stressful" (P6, WA) as it often takes many requests to secure a placement. Difficulties associated with securing placements, along with the time taken to establish relationships and support pre-service teachers, all increase the stress and emotional costs and these are magnified when problems arise with "failing or at risk" pre-service teachers (P7, U).

Other 'hidden costs' were identified as the limitations imposed by the placement model itself, stating that there is little scope for sustainable innovation while the base level payment is required. As explained by P28:

Everything we do is paid for on top of the supervision payment - despite the fact that the model is becoming 
more school based and involves other teachers etc. So it is more about where the money goes and what it is used for than how much there is (P28, VIC).

\subsection{Supervision of Pre-service Teachers}

Provider-participants' concerns over the current models of supervision related to the unclear expectations for both the university academic and the mentor teacher, as described by P15:

Our challenge is working out the role of the university academic (who has traditionally made some visits to practicum sites) and the role of the teacher mentor. Our policies and practices are not clear as to who does what and why. For example, what is the purpose of academic visits? Is it to support the PST? If so, how does this align with the support offered by the teacher mentor? Is it to visit the partnership? (P15, VIC).

Other participants commented on the difficulties of "inadequate staff to visit and monitor PST" (P9, QLD), and other participants reported, "limited [availability of] external supervisors makes it difficult to visit all students across Australia" (P25, NSW). Concerns also related to the supervision of pre-service teachers related to the difficulty of "ensuring quality mentoring from mentor teachers" (P5, VIC), where "some mentors lack ability to be good mentors" (P6, WA). Relatedly, another participant expressed concern over the difficulties in addressing the equity rights of preservice teachers who identify as having "special needs":

The over-emphasis on the 'rights' of so-called 'Special Needs' students undertaking Teacher Education degrees is to the detriment of the children they will teach, their school-based Supervising Teachers and University-based Tertiary Supervisors. It is a blight on the profession and causes untold damage to the image of both the University as well as those schools unfortunate enough to have incompetent graduates find their way to schools as staff (P8, NSW).

Furthermore, respondents reported on the difficulty of "ensuring quality mentoring from mentor teachers" (P5, VIC), where "some mentors lack ability to be good mentors" (P6, WA). Relatedly, another participant reported that:

The capacity to work with early learning centers/schools/colleges relies on a presence within and relationship with site staffs and this is not the work that is recognised with the performativity of the current context (P22, TAS).

\subsection{University-school Partnerships}

Provider-participants described a number of difficulties concerning university-school partnerships, summarised in Table 3 below:

Table 3. Identified difficulties in establishing university-school partnerships

\begin{tabular}{ll}
\hline Theme & Sub-theme \\
\hline Finding placements & $\begin{array}{l}\text { Difficulties in communication with schools - delayed communication } \\
\text { Availability of placements } \\
\text { 'Exclusive' arrangements between university and school }\end{array}$ \\
& $\begin{array}{l}\text { Geographically isolated } \\
\text { Time commitment }\end{array}$ \\
& $\begin{array}{l}\text { Not enough time allocated in workload to build and maintain } \\
\text { university- school partnerships }\end{array}$ \\
\hline
\end{tabular}

Concerns relating to supporting and maintaining university-school partnerships, included "communication delays" (P18, ACT), a "lack of response from busy school personnel (P17, SA), and "delayed responses to communication i.e. emails, phone calls" (P16, NSW). Participants noted that the "busyness of teachers and school leaders" (P7, U) hindered productive working relationships between universities and schools compounded by the fact that, "schools are busy; universities are not a high priority" (P6, WA).

Other issues relating to managing pre-service teachers to ensure their actions do not further complicate a university's working relationships with individual schools. As one participant explained:

Only the professional experience coordinator negotiates with schools. Stopping students from trying to 'help' by arranging [their]own placements can be challenging; remembered (not necessarily recent) experience of a pre-service teacher who required significant additional support or who was unsuited to teaching can lead [a school]to not wanting more [preservice] students from our university; getting responses from schools to requests in a timely manner (to us its urgent, to them its only one more thing on the to-do list; change of personnel from year to year and finding the right person to deal with this year; need to make more contacts 
to get enough host schools (P19, SA).

In a similar vein, provider-participants commented on the political and legislative structures that constrain and dictate how they establish and maintain connections with schools:

We are at the mercy of two NSW DOE edicts. (1) Although DOE claims to have made it clear to schools that so-called 'Partnerships' are non-exclusive, many schools have chosen to interpret these as exclusive and therefore refuse to take our students. (2) DOE's edict that only teachers who have undertaken accredited Mentorship/Supervisor training can take students on placement has led to many schools refusing our students on the grounds that they have no teachers on staff qualified to do so (P8, NSW).

\section{Discussion}

This study investigated how ITE providers perceive the operationalisation of legislation for professional experience at their institution. Of the 48 ITE providers across Australia, 20 responded to the survey giving a range of $42 \%$ of responses reflecting providers from all states and territories.

Findings showed that ITE providers believe that there is a lack of systemic cohesion between policy at a national, state, sector and school level about operational aspects of professional experience. Of particular significance was that ITE providers reported that, regardless of context or locality, there was ambiguity in expectations for providers and mentors, and hidden costs that affected the provision of programs.

One of the most significant findings of this study is the complexity for those involved with professional experience when there is a lack of clarity in the legislative guidelines for key aspects of professional experience programs. There is a lack of statements, guidelines, values and prescriptions that are necessary to both enable and constrain the models and practices of professional experience programs. In particular, the lack of legislative guidelines for the allocation and distribution of funding means that supervisors are paid (variable amounts) despite there being no legislative obligation to do so and this is a significant impost on providers, requiring them to pay large sums of money to secure placements for their preservice teachers.

In Conditions that Support Early Career Teacher Resilience, Johnson et al (2012) highlight the importance of policies and practices that show a strong commitment to providing relevant, rigorous and responsive pre-service preparation for the ITE profession by creating innovative partnership and initiatives that assist smooth transitions of pre-service teachers to the workforce. However, the findings presented here indicate that the university-school partnerships are hindered by a lack of clarity, particularly in the role of the supervisory teacher, whereby the specific tasks and responsibilities appear to be adopted out of a teachers' professionalism or 'good will', rather than as a required part of their job position.

Previous reports have documented similar issues, most notably the ACDE (2014), which identified concerns relating to the chronic shortage of placements, lack of time for mentor teachers to meet with pre-service teachers, and inadequate time for mentor teachers to include mentoring in their work (ACDE as cited in Le Cornu, 2015). The findings of this study reflect these themes, and shows that as a professional community, we are not yet reaching the goals aspired to by AITSL with respect to making professional experience programs those that "make explicit the elements of high-quality, effective teaching in $21^{\text {st }}$ century schools" (Le Cornu 2015, p. 4).

As we have shown, there is a lack of organised processes in place to recognise the work of supervisors and mentors within professional experience. Participants reported that current funding allocations were inadequate to cater for additional requirements; such as "additional assistance needed for certain students not accounted for in operational costs" (see Table 2).

A further area of concern for all schools and faculties of Education is the budget allocation for placement supervision. School- based coordinators and supervising teachers are all paid a daily rate. There may be additional payments for visiting associates who are employed by providers to help manage the number of site visits they need to take to ensure pre-service teachers have access to university support while they are in the school. Overall, the findings indicate that university-providers find that payment for placements reduces opportunities to use their funds to explore new placements models or to invest in other elements of their ITE programs.

This study reveals the 'hidden costs' associated with professional experience due to the complex demands placed on all professionals who work within ITE professional experience, including both academics and supervisory teachers. The provision of professional experience, reflects "relational work" and takes much "time to build the relationships and maintain these [relationships]" (P21, NSW), and much of this work and time taken to support depends on the dedication of staff from universities and schools. 
Participants commented on other hidden costs, stating that "finding placements is expensive" (P25, NSW), and "stressful" (P6, WA), particularly when pre-service teachers are failing or "at risk" (P7, U). There were also concerns that the "goodwill" required of schools and classroom teachers was not taken into consideration in the professional responsibilities of either university-based supervisors or the school-based professionals.

The "good will" from schools, classroom teachers and university academics toward making professional experience work is not adequately recognised within academic workloads or in the roles of supervisory teachers. As described by one respondent, "professional experience is such a complex space that incorporates so many complex issues (legal, health etc.) and each individual issue is incredibly hard to resolve. The allocation of staffing never adequately meets these pressures" (P22, TAS).

These findings are consistent with the observations of Cohen et al. (2013) on the tensions and conflicts that exist between the individual relationships between mentors, supervisors, and pre-service teachers resulting from different interests, educational philosophies, and status differences. ITE providers reported difficulties in making connections with schools and finding placements for pre-service teachers. This coincides with conclusions of the TEMAG report, that the "quality of placements is influenced by the quality of the partnership between universities and schools, as well as the supervising teachers selected to guide and assess pre-service teachers and how well these teachers are prepared for the role" (TEMAG, 2014). For this to occur there needs to be recognition of the contributions of all stakeholders to this work and increased opportunities for dialogue between them to focus on matters of quality and effectiveness (Gu, 2016).

\subsection{Limitations}

All studies have necessary constraints imposed upon them, and while it is hoped that this study will contribute to ongoing discussions and dialogues on professional experience programs, it nevertheless has a number of limitations. This study is a large study and raises important issues for ITE professional experience. It is noted that the sample size reflects just under half the total number of Australian providers $(n=20$, from a possible 48 providers) and therefore does not represent all possible views of university providers involved in ITE professional experience. Given the limited timeframe involved in the data collection, this article is best considered as a scoping project that provides a broad overview of some of the issues relating to the funding models, mentoring models, and the recognition of the supervisory teacher. This study should be viewed as providing guidance for future comprehensive analyses, as further research is needed to adequately evaluate how legislation might be developed and implemented to guide future practices in relation to the delivery of ITE professional experience.

\section{Conclusion}

Based on the findings in this study, we suggest that for changes to occur at a fundamental level, the legislative directives for current ITE models and practices need to be more closely aligned with the needs and requirements of professional experience programs. Changes are needed to address the needs of both the school and higher education sectors. Specifically, instead of continuing to rely on the altruism of the teaching profession and the low levels of supervisory payments to teachers, it may be necessary to reconceptualise the ways in which recognition and rewards are offered to supervisory teachers and to make this explicit in legislative directives. It may also be necessary to consider the ways in which ITE providers can expand the support that they give to the professional learning needs of both the supervisory teacher and pre-service teachers (Bloomfield, 2009).

Change at this systemic level requires a commitment from Education Authorities to both value the role of professional experience in ITE as well as value the work of supervising teachers. Thus, in reconceptualising models and practices of ITE professional experience, proper attention must be given to the complexity of the policy directives and professional relationships involved.

This study serves to highlight the need to re-address legislation and policy directives regarding the delivery of ITE professional experience. Clearly, any changes or innovations that are implemented in regard to "how prac is done', that is, changes in structures (roles, responsibilities and relationships), must be accompanied by attention to enculturing (changing the shared beliefs, customs, attitudes and expectations) amongst the various stakeholders involved in professional experience. The findings shown this this report coincide with comments by Bullock and Russell (2010), who stated that, "it will take massive efforts to transform the deeply entrenched culture of existing field experience arrangements and practices" (p. 93).

Many of the issues identified in this study relate to the assumed responsibility of key stakeholders and ambiguity around roles and responsibilities that are not supported by legislation. Thus, the significant part may be in redefining and reconceptualising the legislative and policy directives, such that all who participate in 
professional experience may achieve the professional roles and responsibilities defined by AITSL. We conclude this study with the comments by Professor Greg Craven (Chair of TEMAG), in Action Now: Classroom Ready Teachers:

We have concluded that the single most important action to be pursued is the integrated delivery of initial teacher education. This can be achieved through close partnerships between providers, school systems and schools, and underpins improvement to all aspects of the preparation of teachers (TEMAG 2014).

In order to achieve the "integrated delivery" (p. v) aspired to by TEMAG (2014), we need to firstly recognise the assumed responsibility that underpins this statement and then work towards better legislative cohesion relating to funding models, mentoring models, and the role and recognition of supervisors.

The anomalies highlighted in this report resonate with Ball's (2015) concern that "policies are contested, mediated and differentially represented by different actors in different contexts" (p. 311). Without a well-defined policy and legislation to support pre-service teachers in schools and school-university partnerships, an integrated system is difficult to achieve. However, the AITSL program standards (AITSL, 2019a) contributing to developing a common discourse and a national focus on a more integrated approach to ITE, the findings presented in this study are timely in contributing to ongoing discussions regarding legislative directions for professional experience. It is hoped that the findings in this study might highlight the need for substantive policy and legislative changes, such that the goals and objectives for professional experience can be achieved without an overreliance on the goodwill and moral obligations of both academic and teaching staff.

\section{Declaration of conflict of interest}

The author(s) declared no potential conflicts of interest with respect to the research, authorship, and/or publication of this article.

\section{Acknowledgement}

This project was made possible through funding provided by the Federal Department of Training and Education (DET) to ACDE for research on placements in Initial Teacher Education programs.

\section{References}

Aprile, K. T., \& Knight, B. A. (2019). The WIL to learn: students' perspectives on the impact of work-integrated learning placements on their professional readiness. Higher Education Research \& Development, 39(5), 1-14. https://doi.org/10.1080/07294360.2019.1695754

Australian Council of Deans of Education. (2014). ACDE submission to the Teacher Education Ministerial Advisory Group: Teaching for excellence. Retrieved from https://submissions.education.gov.au/Forms/TEMAG/pages/item?SubmissionID=TEM1400196

Australian Institute of Teaching and School Leadership. (2011a). Accreditation of Initial Teacher Education programs in Australia: Standards and procedures. AITSL.

Australian Institute for Teaching and School Leadership. (2011b). Australian professional standards for teachers. AITSL. Retrieved from

https://www.aitsl.edu.au/docs/default-source/national-policy-framework/australian-professional-standards-f or-teachers.pdf?sfvrsn=5800f33c_64

Australian Institute for Teaching and School Leadership. (2014). Early teacher development: trends and reform directions. AITSL.

Australian Institute for Teaching and School Leadership. (2015). Professional experience: participant roles and responsibilities. AITSL.

Australian Institute for Teaching and School Leadership. (2017a). Statement of Intent. Retrieved from https://www.aitsl.edu.au/docs/default-source/default-document-library/statement-of-intent.pdf?sfvrsn=914fe 23c_2

Australian Institute for Teaching and School Leadership. (2017b). Australian Professional Standards for Teachers. Retrieved from https://www.aitsl.edu.au/teach/standards

Australian Institute for Teaching and School Leadership. (2018). One teaching profession: Teacher registration in Australia. Retrieved from https://www.aitsl.edu.au/teach/national-review-of-teacher-registration

Australian Institute for Teaching and School Leadership. (2019a). Accreditation of initial teacher education programs in Australia: Standards and procedures. AITSL. Retrieved from 
https://www.aitsl.edu.au/tools-resources/resource/accreditation-of-initial-teacher-education-programs-in-aus tralia---standards-and-procedures

Australian Institute for Teaching and School Leadership. (2019b). ITE data report 2019. AITSL. Retrieved from https://www.aitsl.edu.au/docs/default-source/research-evidence/ite-data-report/2019/aitsl-ite-data-report-20 19.pdf

Bahr, N., \& Mellor, S. (2016). Building quality in teaching and teacher education. Australian Council for Educational Research.

Ball, S. J. (2015). What is policy? 21 years later: reflections on the possibilities of policy research. Discourse: Studies in the Cultural Politics of Education, 36(3), 306-313. https://doi.org/10.1080/01596306.2015.1015279

Bloomfield, D. (2009). Working within and against neoliberal accreditation agendas: Opportunities for professional experience. Asia-Pacific Journal of Teacher Education, 37(1), 27-44. https://doi.org/10.1080/13598660802530503

Bullock, S., \& Russell, T. (2010). Does teacher education expect too much from field experience? In T. Falkenberg \& H. Smits (Eds.), Field experiences in the context of reform of Canadian teacher education programs (pp. 91-100). Faculty of Education of the University of Manitoba.

Clinton, J., Anderson, M., Dawson, G., Dawson, A., Bolton, S., \& Mason, R. (2017). Teacher effectiveness systems, frameworks and measures: A review. Australian Government Department of Education and Training.

Cohen, E., Hoz, R., \& Kaplan, H. (2013). The practicum in pre-service teacher education: a review of empirical studies. Teaching Education, 24(4), 345-380. https://doi.org/10.1080/10476210.2012.711815

Council of Australian Governments. (2009). National Partnership Agreement on improving teacher quality. Commonwealth of Australia. Retrieved from http://www.federalfinancialrelations.gov.au/content/npa/education/national-partnership/past/improving_teac her_NP.pdf

Creswell, J. W., \& Poth, C. N. (2018). Qualitative inquiry research design: choosing among five approaches $\left(4^{\text {th }}\right.$ ed.). SAGE Publications.

Denzin, N. K., \& Lincoln, Y. S. (2008). Introduction: The discipline and practice of qualitative research. In N. K. Denzin \& Y. S. Lincoln (Eds.), Strategies of qualitative inquiry (pp. 1-43). Sage Publications.

Department of Education and Training. (2015). Australian Government response - Action now: Classroom ready teachers. Australian Government. Retrieved from https://docs.education.gov.au/system/files/doc/other/150212_ag_response_-_final.pdf

Department of Education and Training. (2016). Standard of Practice. Queensland Government. Retrieved from https://qed.qld.gov.au/workfordet/induction/det/inductionprogramsandresources/Documents/code-of-conduc t-standard-of-practice.pdf

Department of Education and Training. (2017). Cost of delivery of higher education (final report). Retrieved from

https://docs.education.gov.au/system/files/doc/other/deloitte_access_economics_-_cost_of_delivery_of_hig her_education_-_final_report.pdf

Department of Education, Employment and Workplace Relations. (2009). Transforming Australia's Higher Education System. Commonwealth of Australia. Retrieved from http://www.studentsfirst.gov.au/teacher-educationministerial-advisory-group

Gore, J. (2015). Evidence of impact of teacher education programs: A focus on classroom observation. Australian Institute for Teaching and School Leadership.

Green, C., Tindall-Ford, S. K., \& Eady, M. (2019). School-university partnerships in Australia: a systematic literature review. Asia-Pacific Journal of Teacher Education, 48(4), 403-435. https://doi.org/10.1080/1359866X.2019.1651822

Grossman, P. (2010). Learning to practice: The design of clinical experience in teacher preparation. National Education Association.

$\mathrm{Gu}, \mathrm{Q}$. (2016). Connecting higher educaiton and schools: Building partnerships for capacity building and school 
improvement in England. In J. C.-K. Lee \& C. Day (Eds.), Quality and change in teacher education. Professional learning and development in schools and higher education 13. Springer.

https://doi.org/10.1007/978-3-319-24139-5_14

Higher Education Support Act. (2003). (Cth). Retrieved from https://www.legislation.gov.au/Details/C2020C00078

House of Representatives Standing Committee on Education and Vocational Tranining. (2007). Top of the class. Report on the inquiry into teacher education. Retrieved from

https://www.aph.gov.au/parliamentary_business/committees/house_of_representatives_committees?url=evt/ teachereduc/report.htm

Ingvarson, L., Reid, K., Buckley, S., Kleinhenz, E., Masters, G. N., \& Rowley, G. (2014). Best practice teacher education programs and Australia's own programs. Department of Education.

Kruger, T., Davies, A. C., Eckersley, B., Newell, F., \& Cherednichenko, B. (2009). Effective and sustainable university-school partnerships: Beyond determined efforts by inspired individuals. Teaching Australia Australian Institute for Teaching and School Leadership.

Lave, J., \& Wegner, E. (1999). Legitimate peripheral participation in communities of practice. In R. McCormick \& C. Paechter (Eds.) Learning and Knowledge. Paul Chapman. https://doi.org/10.1016/B978-0-7506-7223-8.50010-1

Le Cornu, R. (2010). Changing roles, relationships and responsibilities in changing times. Asia-Pacific Journal of Teacher Education, 38(3), 195-206. https://doi.org/10.1080/1359866X.2010.493298

Le Cornu, R. (2015). Key components of effective professional experience in Initial teacher education in Australia. Australian Institute for Teaching and School Leadership.

Le Cornu, R., \& Ewing, R. (2008). Reconceptualising professional experiences in pre-service teacher education... reconstructing the past to embrace the future. Teaching and Teacher Education, 24(7), 1799-1812. https://doi.org/10.1016/j.tate.2008.02.008

Loughran, J. (2014). Professionally developing as a teacher educator. Journal of Teacher Education, 65(4), 271-283. https://doi.org/10.1177/0022487114533386

Mayer, D. (2014). Forty years of teacher eucation in Australia: 1974-2014. Journal of Education for Teaching, 40(5), 461-473.

McLean, L., Dickson, B., Rickart, F., Dinham, S., Conroy, J., \& Davis, R. (2015). Teaching as a clinical profession: Translational practices in teacher education - an international perspective. Journal of Education for Teaching, 41(5), 1-15. https://doi.org/10.1080/02607476.2015.1105537

Miles, M. B., \& Huberman, A. M. (1994). Qualitative data analysis: An expanded sourcebook (2nd ed.). Sage Publications Ltd.

National Health and Medical Research Council. (2007). National statement on ethical conduct in human research. Australian Government.

National Health and Medical Research Council. (2018). Australian Code for the Responsible Conduct of Research. Australian Government.

NSW Department of Education. (2017). Professional responsibilities. Retrieved from http://www.dec.nsw.gov.au/about-us/careers-centre/school-careers/teaching/your-teaching-career/approved-t eachers/casual-teacher-induction/professional-responsibilities.

Ramsey, G. A. (2000). Quality Matters: Revitalising Teaching: Critical Times, Critical Choices: Executive Summary: Report of the Review of Teacher Education: NSW Department of Education and Training.

Renshaw, P. (2012). Literature review and environmental scan: Supervising professional experience students. Australian Institute for Teaching and School Leadership.

School Education Act. (1999). Retrieved from https://www.legislation.wa.gov.au/legislation/statutes.nsf/law_a1960_currencies.html

School Education Regulations. (2000). Retrieved from https://www.legislation.wa.gov.au/legislation/statutes.nsf/main_mrtitle_2033_homepage.html

Smith, K., \& Lev-Ari, L. (2005). The place of the practicum in pre-service teacher education: The voice of the students. Asia-Pacific Journal of Teacher Education, 33(3), 289-302. 
https://doi.org/10.1080/13598660500286333

Southgate, E., Reynolds, R., \& Howley, P. (2013). Professional experience as a wicked problem in initial teacher education. Teaching and Teacher Education, 31, 13-22. https://doi.org/10.1016/j.tate.2012.11.005

Teacher Education Ministerial Advisory Group. (2014). Action now: Classroom ready teachers. Australian Government. Retrieved from

https://docs.education.gov.au/system/files/doc/other/150212_ag_response_-_final.pdf

Teaching Australia. (2006). Australia-wide accreditation of programs for the professional preparation of teachers: A consultation paper: Teaching Australia.

Victoria State Government (2016). Roles and responsibilities: Teaching service. http://www.education.vic.gov.au/hrweb/Documents/Roles_and_responsibilities-TS.pdf

White, S., Bloomfield, D., \& Le Cornu, R. (2010). Professional experience in new times: Issues and responses to a changing education landscape. Asia-Pacific Journal of Teacher Education, 38(3), 181-193. https://doi.org/10.1080/1359866X.2010.493297

Wilson, E. K. (2006). The impact of an alternative model of student teacher supervision: Views of the participants. Teaching and Teacher Education, 22(1), 22-31. https://doi.org/10.1016/j.tate.2005.07.007

\section{Copyrights}

Copyright for this article is retained by the author(s), with first publication rights granted to the journal.

This is an open-access article distributed under the terms and conditions of the Creative Commons Attribution license (http://creativecommons.org/licenses/by/4.0/). 